\title{
Changes in climate conditions and their effects on production and reproduction of medium yielding cows in temperate continental climate
}

\author{
Silviu-Ionuț Borş? ${ }^{1}$ Iulian Ibănescu ${ }^{1,2}$, Emesse Balla3 , Alina Borş ${ }^{4 *}$
}

\begin{abstract}
'Research and Development Station for Cattle Breeding, 707252 Dancu, Iaşi, Romania
2University of Zurich, Vetsuisse Faculty, Clinic of Reproductive Medicine, 8057 Zurich, Switzerland

3Sapientia Hungarian University of Transylvania, Faculty of Sciences and Arts, Department of International Relations and European Studies, 400112 Cluj-Napoca, Romania

${ }^{4}$ University of Agricultural Sciences and Veterinary Medicine, Faculty of Veterinary

Medicine, Department of Public Health, 700489 lasi, Romania

*Corresponding author: alinasabie@yahoo.com
\end{abstract}

\section{Abstract}

The increased air temperature combined with the reduction of rainfall during hot season impairs the capacity of cows to maintain the optimal body temperature. This study tested the hypothesis that climate changes affect the medium yielding cows in temperate continental climate. The productive-reproductive parameters of 8607 milking cows from a dairy farm in North-eastern Romania were examined and correlated with changes in ambient temperatures and rainfall between the years of 1983 and 2010. We observed that the number of artificial inseminations served to cows showed a decreasing trend. The reduction in this parameter was significantly influenced by the increase in the average and maximum temperatures during hot season associated with the reduction in rainfall, as shown by regression analysis. Other studied parameters such as milk production, calving to conception interval, calving to first artificial insemination interval and conception rates at first, second and more than two services were not related to the changes in average annual temperatures, annual temperatures amplitude and annual precipitation quantities. This study suggests that, although present, the effects of climate changes on some productive-reproductive parameters of medium yielding cows in geographic areas with temperate continental climate are not as dramatic as described in other studies.

Key words: climate parameters, dairy cows, medium yield, cattle breeding

\section{Introduction}

The IPCC ${ }^{1}$ forecast reported that the global average surface temperature may increase up to

1 Intergovernmental Panel on Climate Change is a scientific intergovernmental body set up by the World Meteorological Organization (WMO) and by the United Nations Environment Programme (UNEP). $4^{\circ} \mathrm{C}^{2}$ by the end of this century (IPCC, 2014) which will affect the overall crop production and animal husbandry (Chiotti and Johnston, 1995; Specht and Specht, 1995; Brklacich et al., 2000; Nardone et al., 2010). Previous research has already

2 Representing the best estimate for the A1FI GHG emissions scenario, with a likely range of $2.4-6.4^{\circ} \mathrm{C}$ 
reported that significant changes in physical and biological systems are occurring on all continents in the direction expected with warming temperature (Rosenzweig et al., 2008).

The genetic selection for milk production in dairy cows has increased the metabolic heat output per cow. This has considerably increased the susceptibility of lactating dairy cows to heat stress, diseases and metabolic disorders. A rise in some of the climate variables leads to, or increases the existing heat stress in cattle (Klinedinst et al., 1993; Silanikove, 2000; Rhoads et al., 2009; Dash et al., 2016). Consequently, smaller and younger cows lose heat more easily and they are likely to experience heat stress less rapidly than older or larger cows (Verkerk, 2009).

Not only the projected mean climate changes might have a negative impact on livestock productivity, but also the changes in the frequency and severity of extreme climate events such as drought and flooding events, which are in general strongly correlated with animal losses (Thornton et al., 2009). For example, during a heat wave in 2006 , Californian dairy producers lost an estimated $\$ 1$ billion in milk and animals. In 1999, during a severe heat wave, Nebraska producers lost more than $\$ 20$ million in cattle death and performance losses. Between July 11 and 12, 1995, a combination of heat and humidity caused the death of over 3,700 cattle in thirteen county areas of western lowa (Collier and Zimbelman, 2007). Exposures as short as four days to heat wave conditions are enough to induce heat stress responses and adversely affect production in the lactating dairy cows (Garner et al., 2017).

The climate in Romania is temperate continental with 8 months per year positive temperatures $\left(>0{ }^{\circ} \mathrm{C}\right)$ in south and sea coast areas and 4 months per year positive temperatures in high-mountain areas, with frequent heat waves of $+40^{\circ} \mathrm{C}$ during summer. According to the National Administration of Meteorology in Romania, the year of 2007 was the warmest in the last 107 years, the average thermal regime being much higher than normal. Three heat waves of $+40^{\circ} \mathrm{C}$ occurred in the summer of 2007 in Bucharest and the agricultural production from that year was the lowest in the last century (damages in agriculture were recorded on $65 \%$ of the culture area).
As the dairy industry in Romania is strongly depending on planted pasture (including the local grain production), the climate change is likely to have a negative impact on livestock production. In addition, economic losses could be caused directly by heat stress since it impairs milk production, reproductive rates and immune function (Titto et al., 2017; Spiers et al., 2018). Recently, Dobrinescu et al., (2015) have studied the long term changes and physical mechanisms controlling the variability of Temperature Humidity Index, which is directly implied in human heat and animal stress, for the period 1961-2010. They showed that this index recorded a significant increase trend in Romania, with episodes of extremely high temperature after the year 1985. In Romanian legislation the extremely high temperature episodes are defined when the air temperature exceeds $37^{\circ} \mathrm{C}$ or the equivalent felt temperature, expressed through THI values, exceeds 80 units.

There are clear seasonal patterns of estrus detection, of days to first service and conception rate in dairy cows (Cavestany et al., 1985; Ryan et al., 1993; Roelofs et al., 2010) and the lower conception rates are consistently observed in summer months compared to winter months. Heat stress is considered a major contributing factor to low fertility of dairy cows inseminated in late summer (Thompson et al., 1996; al-Katanani et al., 1999; Garcia-Ispierto et al., 2007; De Rensis et al., 2017).

The aim of this study was to investigate the effects, if any, of some climate parameters and season on the productive-reproductive efficiency of medium yielding cows in temperate continental climate, studying the data from a herd in the North-eastern Romania over a period of 27 years.

\section{Materials and methods}

The data presented in this study were collected over 27 years, between 1983 and 2010, from a dairy farm in North-eastern Romania, near the city of Iași. The dairy cows within the farm originate from a Holstein Friesian core, imported from Denmark in 1965.

During the entire period of study, the cows (n $=8607$ ) were housed using the same technology. 
From April-May to October they were maintained outside in free stalls $(70 \times 30 \mathrm{~m}$ for 80 dairy cows, earthen lots, with shading area $70 \times 5 \mathrm{~m}$ for cooling and rain protection) and for the rest of the year inside, in individual stalls $(2.2 \times 1.2 \mathrm{~m}$, concrete floor, 106 individual stalls in a $72 \times 10$ m housing area). The food ration was constant throughout the period of study with the specification that during hot season the alfalfa silage was replaced with greencut alfalfa and hairy vetch (Table 1). The number of milking cows/year and the number of replacement heifers/year were also constant ( $n=430-440$ and $\mathrm{n}=130-150$ respectively).

TABLE 1. Ingredients of diets for milking cows according to season, within the farm and the period of the study

\begin{tabular}{|c|c|c|}
\hline Ingredient & Summer* & $\begin{array}{l}\text { Rest of } \\
\text { the year }\end{array}$ \\
\hline Alfalfa hay (kg/day) & 2.5 & 3 \\
\hline $\begin{array}{l}\text { Green-cut alfalfa and hairy } \\
\text { vetch (kg/day) }\end{array}$ & $35-40$ & 0 \\
\hline Alfalfa silage (kg/day) & 0 & $6.5-7$ \\
\hline Corn silage (kg/day) & 15 & 25 \\
\hline $\begin{array}{l}\text { Concentrates supplement } \\
\text { (kg/day) }\end{array}$ & $5-6$ & $5-6$ \\
\hline Calcium carbonate (kg/day) & 0.15 & 0.15 \\
\hline $\begin{array}{l}\text { Mineral supplement (kg/ } \\
\text { day) }\end{array}$ & 0.1 & 0.15 \\
\hline
\end{tabular}

*Summer: June-August, Rest of the year: September-May

Various productive and reproductive parameters from the farm were calculated using the data available from the official register which has been completed by the farm veterinarian. Not all parameters were calculated during the same periods of time, due to different availability of data.

The conception rates at first (CR 1S), second (CR $2 \mathrm{~S})$, and more than two services ( $C R>2 S)$, average milk production per farm (AMPF) and per cow (AMPC) were calculated for the period between 1983-2010 and 1995-2010 respectively. The number of artificial inseminations served to cows (No. AIC) and heifers (No. $\mathrm{AlH}$ ) were calculated between 1983-2010 and 19952010 respectively, as parameters that reflect the number of estrus manifestations after the voluntary waiting period. The calving to first artificial insemination interval (CFAl) and the calving to conception interval (CCI) were calculated in the period 1990-2009.
Each cow had a voluntary waiting period of 45 days postpartum. Estrus detection was carried out three times a day using tail paint (which was first applied 15 days postpartum) before and after the voluntary waiting period.

From 1978 until 2011, the same Al technician has performed the artificial inseminations of the cows within the farm. Thus, the operator skills as a factor that could affect the oscillation of success rate in Al were eliminated. The date of conception was estimated by subtracting 280 days from the calving date (Norman et al., 2009).

Climate data were collected from the statistical yearbooks published by the Romanian National Institute of Statistics ${ }^{3}$ (NIS) in the period between 1983 and 2010. These data were registered at the meteorological station in Iaşi ${ }^{4}$. In Romania, the Temperatures Humidity Index ( $\mathrm{THI}$ ) is only available since 2000 with the Governmental decision (Government Emergency Ordinance) 99/2000. In the absence of the THI, we measured the effects of the following climatic variables on some productive-reproductive parameters in dairy cows from the North-eastern Romania: air temperature - monthly and yearly average, absolute minimum and absolute maximum; precipitations (rainfall) - monthly and yearly.

For each of the above mentioned parameters, the mean value and standard error were calculated. Statistical significance of the differences in means during monitored periods was evaluated by one-way analysis of variance (ANOVA) and by Tukey-Kramer Multiple Comparisons Test.

Connections between the monitored variables were detected by Pearson correlation coefficients ( $r$ ). The factors affecting the variation of the studied productive-reproductive parameters were evaluated by regression analysis. Data were processed using IBM SPSS ${ }^{\circledR}$ Statistics version 21 (IBM ${ }^{\circledR}$ Corporation, Chicago, IL, USA). The dependent variables were the studied productive-reproductive parameters while the independent variables were the average annual temperatures, the annual temperatures amplitude and the annual precipitation quantities.

3 Former names: Central Department of Statistics, National Commission for Statistics.

4 Romanian Statistical Yearbook 2011 available at: http:// www.insse.ro/cms/files/Anuar\%20statistic/01/01\%20 Geografie_ro.pdf 


\section{Results and discussion}

\section{Climate variation during the period of 1983-2010 in the studied area}

The evolution of the climate parameters registered in laşi from 1983 to 2010 - aggregated four seasons - is presented in Figure 1, Figure 2, Figure 3 and Figure 4. We observed a general increasing tendency in maximum temperatures, particularly in summer. The absolute minimum temperatures
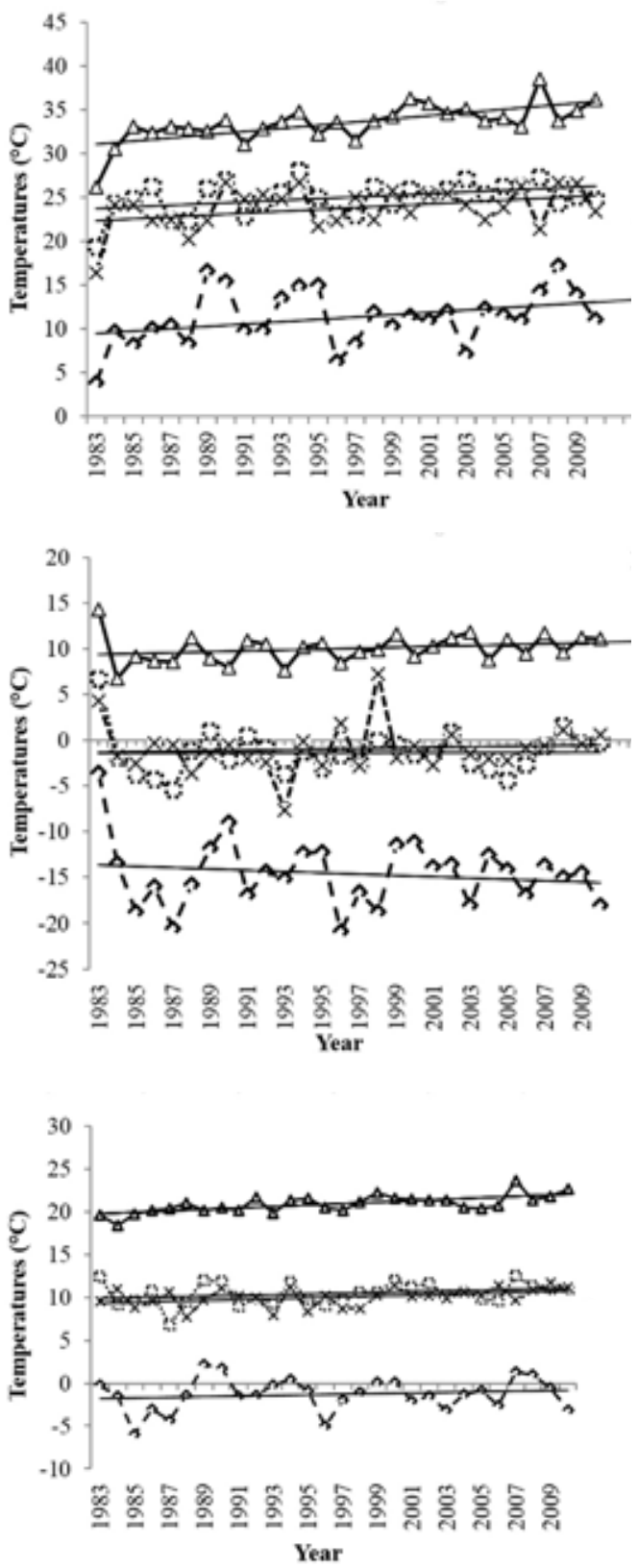

showed an increasing tendency only in summer and autumn while in spring were relatively steady and in winter decreased. Same as the absolute maximum temperatures, the average season temperatures showed an increasing tendency, especially during summer.

The summer and spring precipitation quantities were characterized by a decreasing trend, the steepness being similar. Oppositely, the winter and autumn precipitation quantities showed almost identical magnitude, but an increasing tendency.

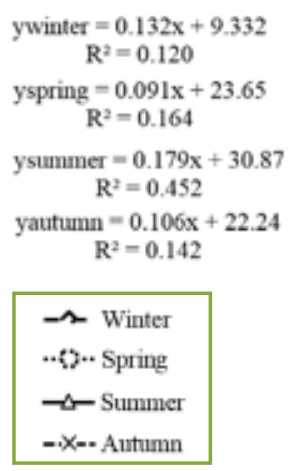

ywinter $=-0.068 x+122.2$
$R^{2}=0.024$

yspring $=0.002 x-6.867$ $\mathrm{R}^{2}=9 \mathrm{E}-05$

ysummer $=0.048 \mathrm{x}-87.06$ $\mathrm{R}^{2}=0.065$

yautumn $=0.026 \mathrm{x}-54.04$ $\mathrm{R}^{2}=0.006$

\section{- Winter \\ *\%.. Spring \\ $\rightarrow-$ Summer \\ -’x-- Autumn}

FIGURE 1. The evolution of maximum seasonal temperatures in laşi, Romania, 1983-2010 Source: own editing based on data from Romanian National Institute of Statistics Winter = Dec-Feb; Spring = Mar-May; Summer = Jun-Aug; Autumn $=$ Sep-Nov
FIGURE 2. The evolution of minimum season temperatures in laşi, Romania, 1983-2010 Source: own editing based on data from Romanian National Institute of Statistics Winter = Dec-Feb; Spring = Mar-May; Summer = Jun-Aug; Autumn = Sep-Nov

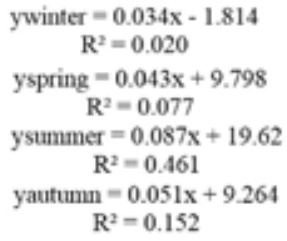

- W Winter

.*3. Spring

$\rightarrow-$ Summer

-) X-- Autumn
FIGURE 3. The evolution of the average seasonal temperatures in laşi, Romania, 1983-2010 Source: own editing based on data from Romanian National Institute of Statistics Winter = Dec-Feb; Spring = Mar-May; Summer = Jun-Aug; Autumn = Sep-Nov 


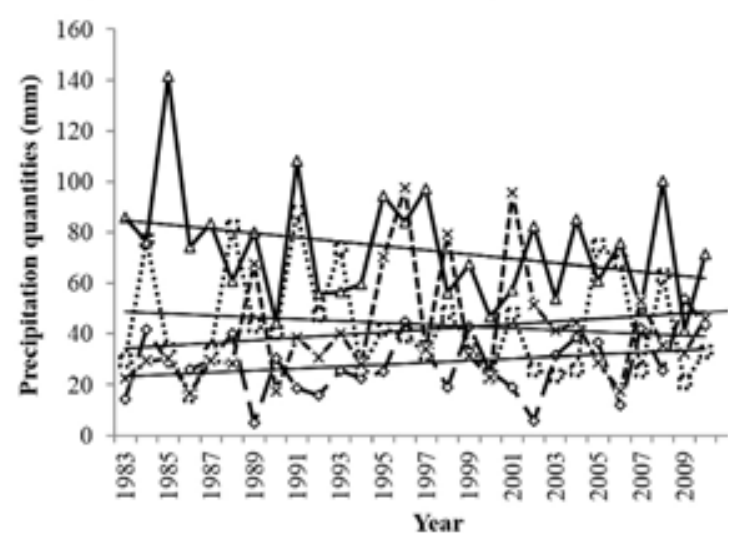

Changes in productive-reproductive parameters of dairy cows and correlations among variables

The milk production has not increased from 1995 to 2010 ( $P>0.05)$ and has not been correlated with the evolution of average annual tem-

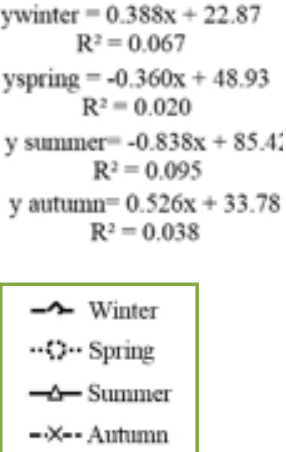

FIGURE 4. Variation of the average seasonal precipitations in laşi, Romania, 1983-2010 Source: own editing based on data from Romanian National Institute of Statistics Winter $=$ DecFeb; Spring = Mar-May; Summer = Jun-Aug; Autumn $=$ Sep-Nov

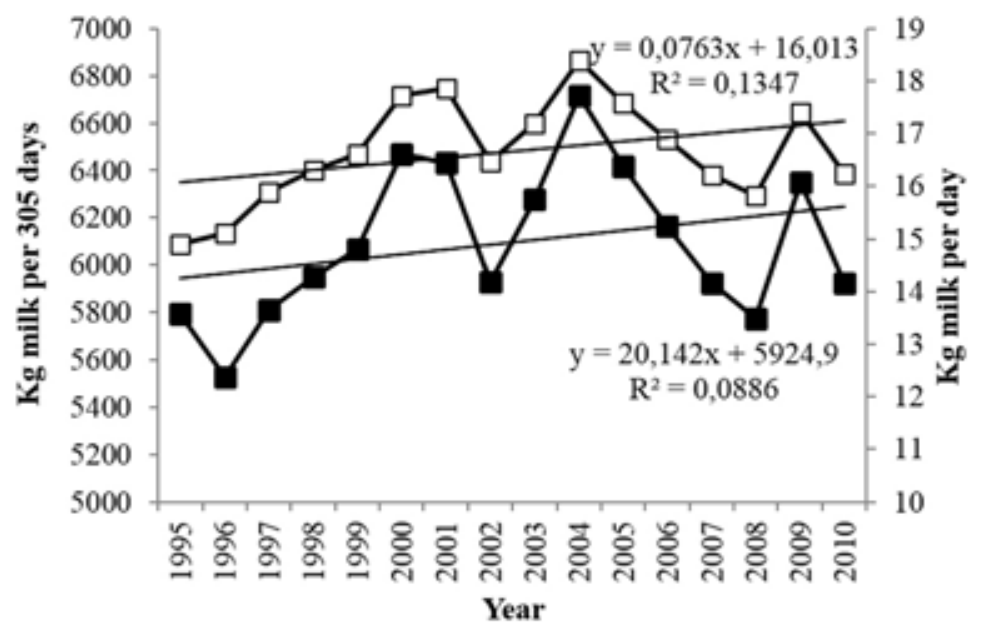

FIGURE 5. Average milk production within the studied farm between 1995 and 2010: kg milk per 305 days ( $)$ and kg milk per day $(\square)$

-Kg milk per 305 days $-\square-\mathrm{Kg}$ milk per day

The number of artificial inseminations served to cows (Figure 6) decreased from 1983 to 2010 $\left(R^{2}=0.82, P<0.01\right)$ and was negatively correlated to the average annual temperatures $(r=-0.62, P<0.05)$, to average temperatures from March ( $r=-0.5$, $\mathrm{P}<0.05)$, September $(r=-0.64, \mathrm{P}<0.01)$ and to max- imum temperatures from March ( $r=-0.58, P<0.05)$, September $(r=-0.57, P<0.05)$. No valid correlation was observed between the number of artificial inseminations served to heifers and the climatic variables $(\mathrm{P}>0.05)$. 


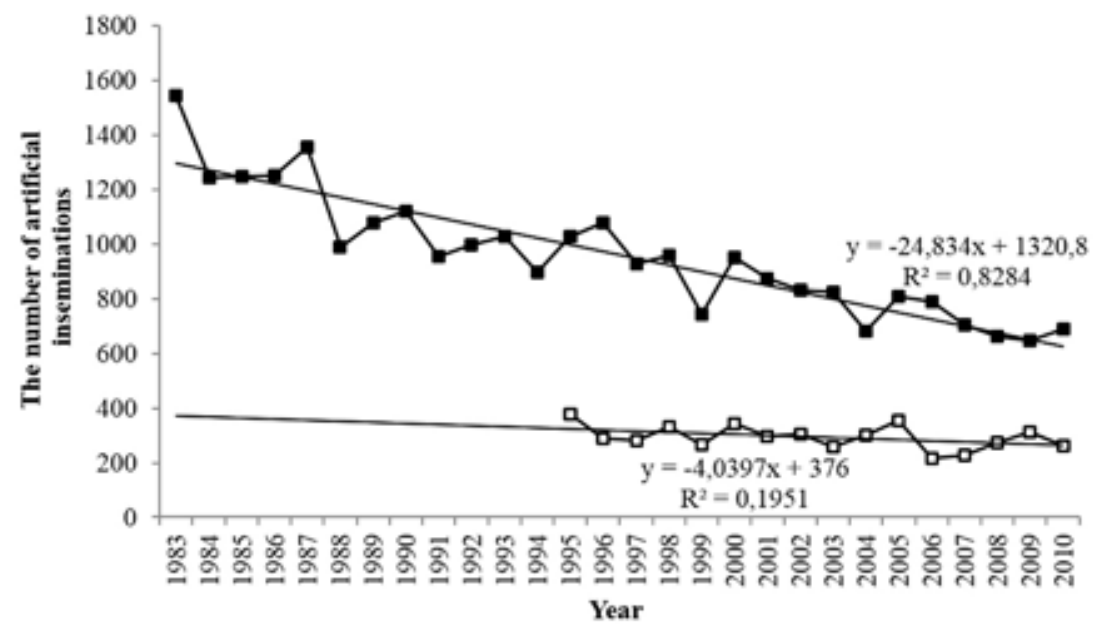

FIGURE 6. Total number of artificial inseminations served to cows ( $\boldsymbol{\square})$ and heifers ( $\square$ ) within the studied farm, per year from 1983 to 2010, respectively 1995 to 2010

During the period 1983-2010, July-November represented the main breeding season with peaks in August, September and October $(\mathrm{P}<0.01)$ (Figure 7). The conception rates (\%) at first services (Figure 8) were higher in October, November, December and January $(P<0.01)$, positively correlated with the maximum temperatures from September $(r=0.38, P<0.05)$, with the rainfall quantities from July $(r=0.58, P<0.01)$ and negatively correlated with the rainfall quantities from June $(r=-0.49, P<0.01)$. The conception rates at second services (Figure 8) were higher in January, March, September and October $(P<0.01)$, positively correlated with the rainfall quantities from March $(r=0.45, P<0.05)$ and negatively correlated with the rainfall quantities from April $(r=-0.56, P<0.01)$ and with minimum temperatures from March $(r=-0.48, P<0.05)$. The most sensitive to climatic variables was the conception rate at more than two services (Figure 8), which was negatively correlated with the average temperatures from February $(r=-0.46, P<0.05)$, July $(r=-0.62, P<0.01)$, August $(r=-0.39, P<0.05)$ and November $(r=-0.39, P<0.05)$, with the maximum temperatures from February $(r=-0.5, P<0.01)$, June $(r=-0.3, P<0.05)$, July $(r=-0.57, P<0.01)$, August $(r=-$ $0.54, P<0.01)$, October $(r=-0.39, P<0.05)$ and November $(r=-0.44, P<0.05)$ and positively correlated with the rainfall amounts from March ( $r=0.51$, $\mathrm{P}<0.01)$ and June $(r=0.41, \mathrm{P}<0.05)$.

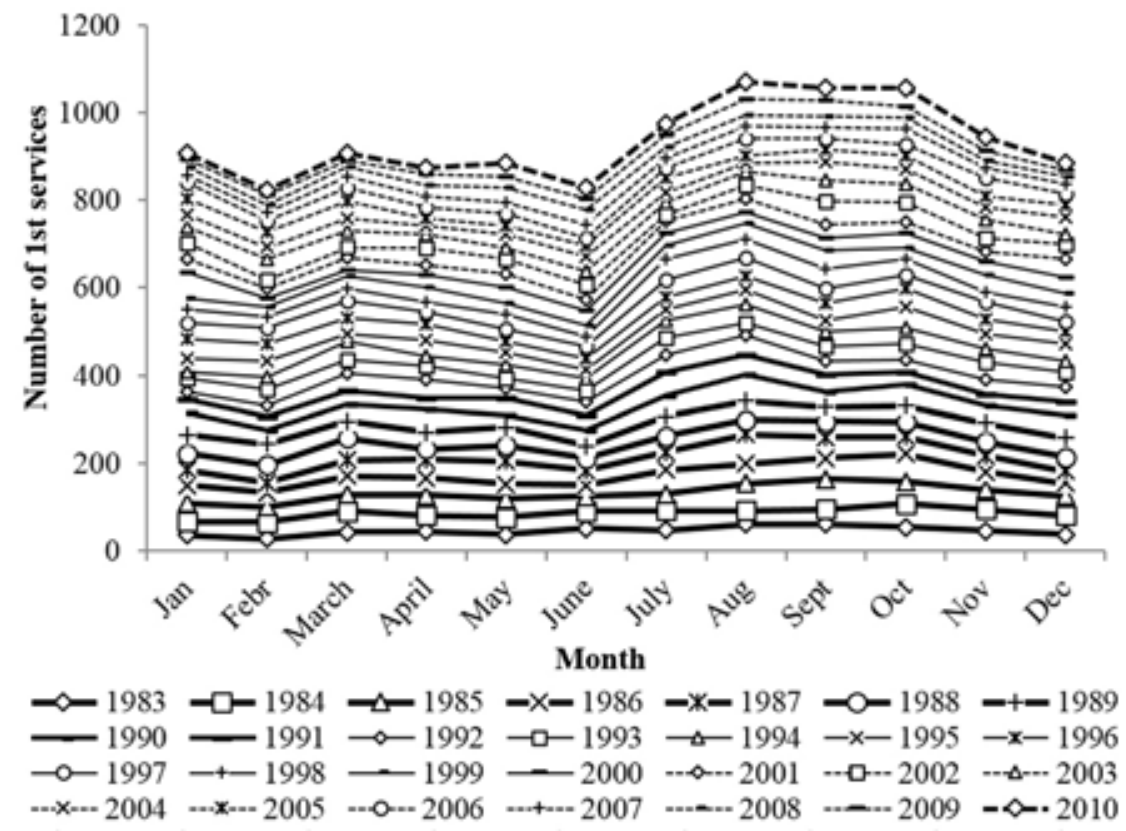

FIGURE 7. Monthly distribution of first sevices within the studied farm, each year from 1983 to 2010 


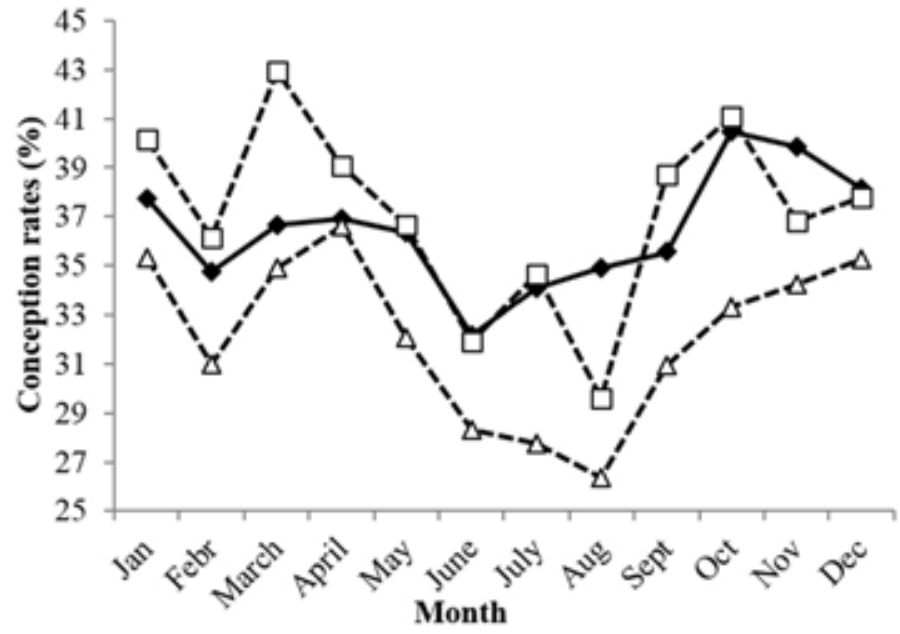

FIGURE 8. Monthly distribution of the conception rate at first service (CR 1S), at second service (CR 2S) and after more than two services (CR $>2 \mathrm{~S}$ ) within the studied farm, between 1983 and 2010

The calving to first artificial insemination interval values in the years 1991, 1997, 2000-2005 compared (CFAl) presented the lowest values in the year interval 1990-2001 (Figure 9) and after this period the values increased until $2007(\mathrm{P}<0.01)$. The evolution of the CFAl was positively correlated with the maximum temperatures from May ( $r=0.44, P<0.05)$, July $(r=0.48$, $\mathrm{P}<0.05)$ and negatively correlated with the maximum temperatures from November $(r=-0.52, P<0.05)$. Also, the rainfall amounts from January were positively correlated with the CFAl $(r=0.46, P<0.05)$. The calving to conception interval (Figure 9) presented the smallest with the other years $(\mathrm{P}<0.01)$.

The calving to conception interval $(\mathrm{CCl})$ was positively correlated with the average temperatures from June ( $r=0.46, P<0.05)$, July $(r=0.43, P<0.05)$ and October $(r=0.46, P<0.05)$, with the maximum temperatures from July $(r=0.45, P<0.05)$, and rainfall amounts from January $(r=0.46, P<0.05)$ and negatively correlated with the maximum temperatures from November $(r=-0.52, P<0.05)$ and rainfall quantities from July $(r=-$ $0.48, P<0.05)$.

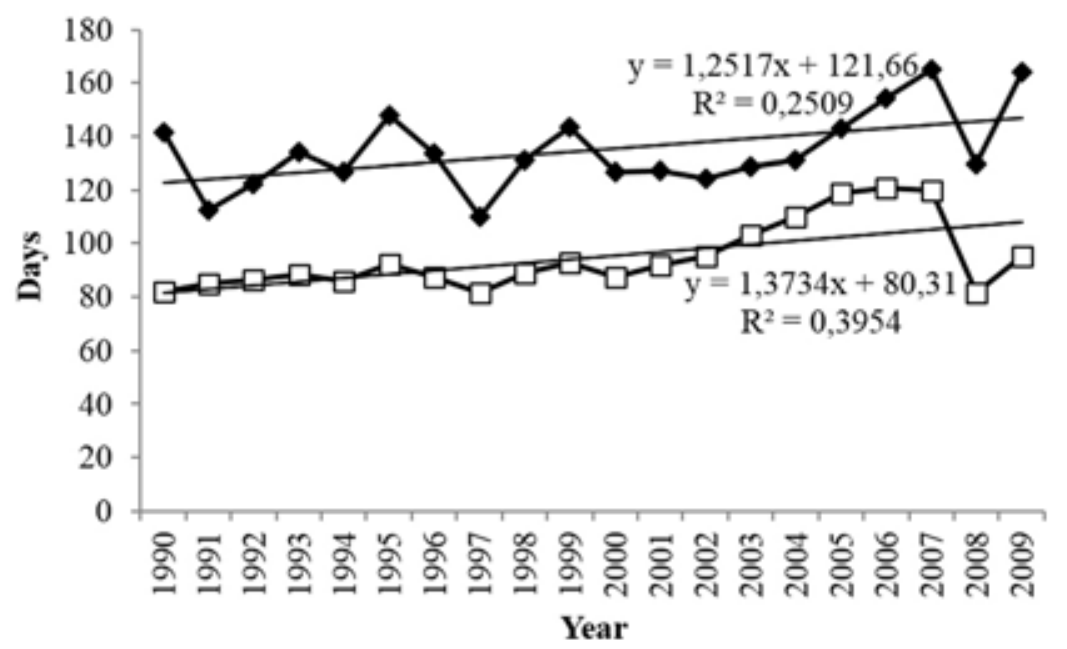

FIGURE 9. Average interval from calving to first artificial insemination (CFAI) and the average interval from calving to conception (CCI) within the studied farm, per year from 1990 to 2009

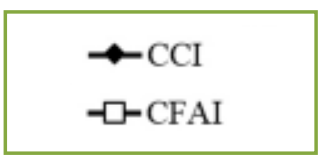

Regression analysis

The regression analyses showed no interaction among average annual temperatures, annual temperatures amplitude, annual precipitation quantities and average milk production ( $\mathrm{P}>0.05)$. No connection was detected either between these three climatic variables and CFAl, CCI, No. AlH, CR 1S, CR 2S an CR
$>2 S(P>0.05)$. The average annual temperatures, the annual temperatures amplitude and the annual precipitation quantities were related, as shown by the regression analysis, only with the number of artificial inseminations served to cows $\left(R^{2}=0.23, P<0.01\right.$; $\left.R^{2}=0.01, P<0.05 ; R^{2}=1 E-05, P<0.05\right)$. 
It is widely acknowledged that global warming presents a significant risk to the welfare of plants and animals, including humans. The National Meteorology Administration of Romania (NMA) reported an increase of the average temperature with 2 ${ }^{\circ} \mathrm{C}$ in the winter and with $3.5^{\circ} \mathrm{C}$ (North) and 4.5 ${ }^{\circ} \mathrm{C}$ (South) in the summer by projections of global scenarios 1991-2099 compared to 1961-1990. Under the conditions of climate change, the aim of this study was to observe whether or not some effects are relevant for the evolution of some productive-reproductive parameters of medium yielding cows. Such approach is only relevant if the period taken into consideration is long enough to comprise multiple generations of cows, held in the same farm and under constant management as regards housing and nutrition.

Our study revealed a significant relation between some climate parameters and the reduction in the number of estrus manifestation of dairy cows, which is consistent with previous findings (Collier et al., 2008). Warming alters heat exchange between animal and environment, affecting the feed intake, mortality, growth, reproduction, maintenance, and production (Thornton et al., 2009). The approximate thermal-comfort zone for optimum performance of adult cattle was reported to be $5-15^{\circ} \mathrm{C}$ and the upper critical temperature of dairy cattle is lower than other livestock species (Sirohi and Michaelowa, 2007), which makes them more susceptible to heat stress.

We found a negative relation of the number of artificial inseminations served to cows with the average and maximum temperatures from March (spring) and September (autumn). It is possible that the low rate of estrus manifestations in March is in fact a result of other stress factors specific to cold season, whose cumulated effects are best visible in March, such as long periods with low temperatures coupled with lack of exercise due to tie-stall system. These environmental changes may, for example, amplify the physiological and nutritional stress occurring at calving, thus affecting the reproductive performance. As for the negative relation between temperatures in September and number of artificial insemination, this could be a result of prolonged heat stress from summer, whose effects may also be visible in autumn (De Rensis and Scaramuzzi, 2003). It is also notable that the increase in average annual temperature coupled with the reduction of rainfall in hot season negatively influenced the number of artificial inseminations, as shown by regression analysis. Previous studies have observed the effects of increasing temperatures and disturbances in precipitations on various productive and reproductive parameters in livestock and in various areas (Thornton et al., 2009). Our study suggests that this phenomenon is also present in areas with temperate continental climate, however, only for a few reproductive parameters in cows with medium milk yield. Lactation is characterized by a high metabolic priority within the organism of the lactating animal thus competing with other metabolic processes and therefore a higher milk yield might be associated with a higher risk of metabolic disturbances. It is noteworthy that the milk production remained constant within the farm included in our study and was at the medium level for Holstein cows breed, which eliminates the milk production as a factor which may be responsible for influencing our results. Other factors such as breed, nutrition and housing system were also constant throughout the survey.

We found that the most favorable period for breeding in the studied cows is the period of July -November (summer and autumn) but the most fertile one is October-January (autumn and winter). Thus, the conception rate at first service were correlated with the increasing temperatures from September. This was surprising, as increased temperatures have been proved to bear negative effects on productive and reproductive parameters of dairy cows. Several alteration in reproduction of cattle can be normally observed during hot season, described as summer infertility (De Rensis et al., 2017). For example, in summer the motor activity and other manifestations of estrus are reduced (Hansen and Aréchiga, 1999; Leyva et al., 2016) and the incidence of anestrous and silent ovulations are increased (Wakayo et al., 2015). Nebel et al., (1997) reported that Holsteins in estrus during the summer had 4.5 vs. 8.6 mounts per estrus for those in winter. Heat stress reduces the size of estrus follicle (Schuller et al., 2017), impairs follicle selection and increases the length of follicular waves; thus, it reduces the quality of oocytes and modulates follicular steroidogenesis (Roth et al., 2001). It has also been proved that summer heat stress increases the number of subordinate follicles, while reducing the degree of dominance of the 
dominant follicle, and decreases the inhibin and estrogen levels (Wolfenson et al., 1995; Wilson et al., 1998). A possible explanation for our unexpected results could be that summer brings a change in the housing system and nutrition of dairy cows within the farm where our study was performed. As such, in May the cows are moved outside in free stalls having full access to exercise. In addition, in summer months cows are fed green-cut alfalfa, which was reported to have beneficial effects upon the reproductive performance of dairy cows through its high beta-carotene content, increasing calf weight at birth, reducing the interval between mating and calving and stimulating the milk yield (Mauriès, 2003).

Besides the change in the housing system and nutrition of cows, the milk yield could also explain the lack of significant decreases in reproductive parameters of the studied cows during summer. The average yield was approximately 6300-6400 kg milk per year, which is at the middle level for the Holstein Friesian cattle. Heat stress is, however, more visible on cows with higher milk production (Das et al., 2016; Heinicke et al., 2018) due to metabolic overload, while cows with low milk production are more resistant to increased environmental temperatures. For example, Purwanto et al. (1990) revealed that cows at high $(31.6 \mathrm{~kg} / \mathrm{d})$ and medium $(18.5 \mathrm{~kg} / \mathrm{d})$ milk yield had 48.5 and $27.3 \%$ greater heat production than dry cows. As the core body temperature is dependent on the balance between the rates of heat gain and heat loss, greater milk production increases thermal strain during periods of elevated ambient temperature (Spiers et al., 2018).

The conception rates at more than two services showed a significant decrease, influenced by the temperatures and rainfall amounts from certain months. The fertility of cows was in general negatively influenced by the reduction of rainfall during summer. This was easy to anticipate, as low amounts of rainfall over a prolonged period are a sign of draught, which was reported to have negative effects on livestock (Thornton et al., 2009). It was however surprising to observe that the conception rate at first service was in fact positively influenced by the reduction of rainfall from June, although the further reduction of rainfall through July impaired this parameter too. A possible explanation could be the same beneficial effects of dietary supplements with green cut alfalfa and full access to exercise starting with May.
We observed an increase in the interval from calving to conception over the period of study, which was related to the increase in average temperatures from June, July (summer), October (autumn) and also the increase of the maximum temperatures from July (summer), associated with the reduction of the rainfall quantities from summer. This shows that the increasing temperatures associated with the reduction of the rainfall in the summer reduced the conception capacity of cows in spite of changing the alfalfa silage with greencut alfalfa and hairy vetch. An improvement was determined by the increase of the maximum temperatures from November (autumn).

The interval from calving to first artificial insemination increased due to the rise of the maximum temperatures in May (spring) and July (summer), while its decrease coincided with increasing the maximum temperatures in November. This leads again to the idea of thermal-comfort zone for optimum performance of adult cattle, which was reported to be 5-15 ${ }^{\circ} \mathrm{C}$ (Sirohi and Michaelowa, 2007). Through increases of temperatures in November the environment was maintained closer to comfortable temperatures.

The challenges for development are already considerable, and there is now a general concern that modifying climate variability will compound these (Thornton et al., 2009). Although negative effects of the climate change will be very subtle over time and hard to track, we need broad understanding of the likely impacts of climate change on the food resources and further actions in animal breeding must be taken accordingly. It is necessary to develop tracking tools and make them available for all producers. In our opinion, only few dairy producers track their operation efficiencies, and they rarely link responses to yearly weather and climate events like heat waves and other extreme weather conditions. However, there is more and more evidence that increasing temperatures have a strong impact on highly productive animals, although our study suggests that the effects are not dramatic when the milk production is only at medium level. The appropriate strategies to counteract the negative effects of climate changes on livestock may include genetic selection based on resistance to heat stress (Hansen and Aréchiga, 1999; Gantner et al., 2019) as well as development of feeding and housing systems that protect the animals against unfavourable environmental conditions (Gauly et 
al., 2013; Spiers et al., 2018). Nevertheless, milk yield is a noteworthy factor that may be considered when heat stress is a threatening forecast.

\section{Conclusions}

Over the period taken into study, the cows suffered a significant reduction in the number of estrus manifestations. However, other parameters were not significantly affected, suggesting a higher resistance of medium yielding cows against studied climate parameters. Clear seasonal effects were also observed. The best breeding interval was between July and November, which is late summer and autumn, despite the evidence of increasing air temperatures and the reduced rainfall quantities. This effect was possibly determined by the foraging of cows with green-cut alfalfa and hairy vetch associated with the full access to exercise in the hot season, as we observed a coincidence of this shift in farm management with an improvement of estrus manifestations during summer. Although it was not possible to draw a strong conclusion on this matter after our study, this could be a hint that green-cut alfalfa associated with full access to exercise could represent a good method to reduce the length and intensity of heat stress during hot season, thus improving the reproductive parameters of dairy cows. Further efforts should be made for developing specific tools to link the farm efficiency to climate changes as well as strategies to counteract the presumable negative effects on livestock.

\section{Acknowledgements}

The authors would like to thank Simona Vlad-Sabie for constructive criticism of the manuscript and for English revision. Also, we would like to thank SCDCB Dancu, lași, for providing the data recorded during the studied period.

\section{Conflicts of interest}

The authors declare no conflicts of interest.

\section{Promjene klimatskih uvjeta i njihovi učinci na proizvodnju i reprodukciju krava prosječne proizvodnje u umjereno kontinentalnoj klimi}

\section{Sažetak}

Povećana temperatura zraka u kombinaciji sa smanjenjem oborina tijekom razdoblja vrućine smanjuje sposobnost krava za održavanje optimalne tjelesne temperature. Ova studija testirala je hipotezu da klimatske promjene utječu na krave prosječne proizvodnje u umjereno kontinentalnoj klimi. Produktivno-reproduktivni parametri 8607 muznih krava u sjeveroistočnoj Rumunjskoj ispitani su i korelirani s promjenama temperature okoline i padalinama između 1983. i 2010. godine. Uočeno je da je broj umjetnih osjemenjivanja pokazao opadajući trend. Na smanjenje ovog parametra značajno je utjecalo povećanje prosječne i maksimalne temperature u vrućim razdobljima godine povezanim sa smanjenjem oborina, što je pokazala regresijska analiza. Ostali ispitivani parametri, kao što su proizvodnja mlijeka, razdoblje teljenja do ponovne koncepcije, razdoblje teljenja do prvog intervala umjetne oplodnje i stope začeća u prvoj, drugoj i više od dva osjemenjivanja nisu se odnosili na promjene u prosječnim godišnjim temperaturama, godišnjim amplitudama temperatura i godišnjim količinama oborina. Ova studija sugerira da, iako su prisutni, učinci klimatskih promjena na neke produktivno-reproduktivne parametre krava prosječne proizvodnje u geografskim područjima s umjerenom kontinentalnom klimom nisu tako dramatični kao što je opisano u drugim istraživanjima.

\section{Ključne riječi: klimatski parametri, mliječne krave, srednji prinos, uzgoj stoke}


1. al-Katanani, Y.M., Webb, D.W., Hansen, P.J. (1999): Factors affecting seasonal variation in 90-day nonreturn rate to first service in lactating Holstein cows in a hot climate. Journal of Dairy Science 82, 2611-2616. https://doi.org/10.3168/jds.S0022-0302(99)75516-5

2. Brklacich, M., Bryant, C., Veenhof, B., Beauchesne, A. (2000): Agricultural adaptation to climatic change: a comparative assessment of two types of farming in Central Canada. In: Millward H, B.K., Ilbery B, Harrington L. (Ed.), Agricultural and Environmental Sustainability in the New Countryside. Hignell Printing Limited, Winnipeg, pp. 50-51.

3. Cavestany, D., el-Wishy, A.B., Foote, R.H. (1985): Effect of season and high environmental temperature on fertility of Holstein cattle. Journal of Dairy Science 68, 1471-1478. https://doi.org/10.3168/jds.S0022-0302(85)80985-1

4. Chiotti, Q.P., Johnston, T. (1995): Extending the boundaries of climate change research: a discussion on agriculture. Journal of Rural Studies 11, 335-350. https://doi.org/10.1016/0743-0167(95)00023-G

5. Collier, R.J., Bilby, T.R., Rhoads, M.E., Baumgard, L.H., Rhoads, R.P. (2008): Effects of climate change on dairy cattle production. Annals of Arid Zone 47, 393-411.

6. Collier, R.J., Zimbelman, R.B. (2007): Heat stress effects on cattle: What we know and what we don't know., $22^{\text {nd }}$ Annual Southwest Nutrition \& Management Conference, Tempe, AZ, pp. 76-83.

7. Das, R., Sailo, L., Verma, N., Bharti, P., Saikia, J., Imtiwati, Kumar, R. (2016): Impact of heat stress on health and performance of dairy animals: A review. Veterinary World 9, 260-268. https://doi.org/10.14202/vetworld.2016.260-268

8. Dash, S., Chakravarty, A.K., Singh, A., Upadhyay, A., Singh, M., Yousuf, S. (2016): Effect of heat stress on reproductive performances of dairy cattle and buffaloes: A review. Veterinary World 9, 235-244. https://doi.org/10.14202/vetworld.2016.235-244

9. De Rensis, F., Lopez-Gatius, F., Garcia-Ispierto, I., Morini, G., Scaramuzzi, R.J. (2017): Causes of declining fertility in dairy cows during the warm season. Theriogenology 91, 145-153. https://doi.org/10.1016/j.theriogenology.2016.12.024

10. De Rensis, F., Scaramuzzi, R.J. (2003): Heat stress and seasonal effects on reproduction in the dairy cow-a review. Theriogenology 60, 1139-1151. https://doi.org/10.1016/S0093-691X(03)00126-2

11. Dobrinescu, A., Busuioc, A., Birsan, M.V., Dumitrescu, A., Orzan, A. (2015): Changes in thermal discomfort indices in Romania and their connections with large-scale mechanisms. Climate Research 64, 213-226. https://doi.org/10.3354/cr01312

12. Garcia-Ispierto, I., Lopez-Gatius, F., Bech-Sabat, G., Santolaria, P., Yaniz, J.L., Nogareda, C., De Rensis, F., LopezBejar, M. (2007): Climate factors affecting conception rate of high producing dairy cows in northeastern Spain. Theriogenology 67, 1379-1385.

https://doi.org/10.1016/j.theriogenology.2007.02.009
13. Garner, J.B., Douglas, M., Williams, S.R.O., Wales, W..., Marett, L.C., DiGiacomo, K., Leury, B.J., Hayes, B.J. (2017): Responses of dairy cows to short-term heat stress in controlled-climate chambers. Animal Production Science 57, 1233-1241. https://doi.org/10.1071/AN16472

14. Gauly, M., Bollwein, H., Breves, G., Brügemann, K., Dänicke, S., Daş, G., Demeler, J., Hansen, H., Isselstein, J., König, S., Lohölter, M., Martinsohn, M., Meyer, U., Potthoff, M., Sanker, C., Schröder, B., Wrage, N., Meibaum, B., von Samson-Himmelstjerna, G., Stinshoff, H., Wrenzycki, C. (2013): Future consequences and challenges for dairy cow production systems arising from climate change in Central Europe - a review. Animal 7, 843-859. https://doi.org/10.5167/uzh-72601

15. Gantner V., Bobić T., Potočnik K., Gregić M., Kučević D. (2019): Persistence of heat stress effect in dairy cows, Mljekarstvo 69, 30-41. https://doi.org/10.15567/mljekarstvo.2019.0103

16. Hansen, P.J., Aréchiga, C.F. (1999): Strategies for managing reproduction in the heat-stressed dairy cow. Journal of Animal Science 77 Suppl 2, 36-50. https://doi.org/10.2527/1997.77suppl_236x

17. Heinicke, J., Hoffmann, G., Ammon, C., Amon, B., Amon, T. (2018): Effects of the daily heat load duration exceeding determined heat load thresholds on activity traits of lactating dairy cows. Journal of Thermal Biology 77, 67-74. https://doi.org/10.1016/j.jtherbio.2018.08.012

18. IPCC (2014): Climate Change 2014: Synthesis Report; Contribution of Working Groups I, II and III to the Fifth Assessment Report of the Intergovernmental Panel on Climate Change. Geneva, Switzerland.

19. Klinedinst, P.L., Wilhite, D.A., Hahn, G.L., Hubbard, K.G. (1993): The potential effects of climate change on summer season dairy cattle milk production and reproduction. Climatic Change 23, 21-36. https://doi.org/10.1007/BF01092679

20. Leyva, C., Aguilar, D., Morales, J.L., Perez-Lopez, S., Veliz, F.G., Soto-Dominguez, A., Moran Martinez, J. (2016): Effects of small dose estradiol cypionate after artificial insemination on reproductive performance in Holstein cows. Journal of Applied Animal Research 44, 24-26. https://doi.org/10.1080/09712119.2014.987290

21. Mauriès, M. (2003): Luzerne: culture, récolte, conservation, utilisation. France Agricole Editions, Paris.

22. Nardone, A., Ronchi, B., Lacetera, N., Ranieri, M.S., Bernabucci, U. (2010): Effects of climate changes on animal production and sustainability of livestock systems. Livestock Science 130, 57-69. https://doi.org/10.1016/j.livsci.2010.02.011

23. Nebel, R.L., Jobst, S.M., Dransfield, M.B.G., Pandolfi, S.M., Bailey, T.L. (1997): Use of radio frequency data communication system, HeatWatch $^{\circledR}$, to describe behavioral estrus in dairy cattle. Journal of Dairy Science 80, 179.

24. Norman, H.D., Wright, J.R., Kuhn, M.T., Hubbard, S.M., Cole, J.B., VanRaden, P.M. (2009): Genetic and environmental factors that affect gestation length in dairy cattle. Journal of Dairy Science 92, 2259-2269. https://doi.org/10.3168/jds.2007-0982 
25. Purwanto, B.P., Abo, Y., Sakamoto, R., Furumoto, F., Yamamoto, S. (1990): Diurnal patterns of heat production and heart rate under thermoneutral conditions in Holstein Friesian cows differing in milk production. Journal of Agricultural Science 114, 139-142. https://doi.org/10.1017/S0021859600072117

26. Rhoads, M.L., Rhoads, R.P., VanBaale, M.J., Collier, R.J., Sanders, S.R., Weber, W.J., Crooker, B.A., Baumgard, L.H. (2009): Effects of heat stress and plane of nutrition on lactating Holstein cows: I. Production, metabolism, and aspects of circulating somatotropin. Journal of Dairy Science 92, 1986-1997. https://doi.org/10.3168/jds.2008-1641

27. Roelofs, J., Lopez-Gatius, F., Hunter, R.H., van Eerdenburg, F.J., Hanzen, C. (2010): When is a cow in estrus? Clinical and practical aspects. Theriogenology 74, 327-344. https://doi.org/10.1016/j.theriogenology.2010.02.016

28. Rosenzweig, C., Karoly, D., Vicarelli, M., Neofotis, P., Wu, Q., Casassa, G., Menzel, A., Root, T.L., Estrella, N., Seguin, B., Tryjanowski, P., Liu, C., Rawlins, S., Imeson, A. (2008): Attributing physical and biological impacts to anthropogenic climate change. Nature 453, 353-357. https://doi.org/10.1038/nature06937

29. Roth, Z., Arav, A., Bor, A., Zeron, Y., Braw-Tal, R., Wolfenson, D. (2001): Improvement of quality of oocytes collected in the autumn by enhanced removal of impaired follicles from previously heat-stressed cows. Reproduction 122, 737-744. https://doi.org/10.1530/rep.0.1220737

30. Ryan, D.P., Prichard, J.F., Kopel, E., Godke, R.A. (1993): Comparing early embryo mortality in dairy cows during hot and cool seasons of the year. Theriogenology 39, 719-737. https://doi.org/10.1016/0093-691X(93)90257-6

31. Schuller, L.K., Michaelis, I., Heuwieser, W. (2017): Impact of heat stress on estrus expression and follicle size in estrus under field conditions in dairy cows. Theriogenology 102 , 48-53. https://doi.org/10.1016/j.theriogenology.2017.07.004

32. Silanikove, N. (2000): Effects of heat stress on the welfare of extensively managed domestic ruminants. Livestock Production Science 67, 1-18. https://doi.org/10.1016/S0301-6226(00)00162-7

33. Sirohi, S., Michaelowa, A. (2007): Sufferer and cause: Indian livestock and climate change. Climatic Change 85, 285-298. https://doi.org/10.1007/s10584-007-9241-8

34. Specht, R.L., Specht, A. (1995): Global warming: predicted effects on structure and species richness of mediterranean ecosystems in southern Australia. In: Roy, J., Aronson, J., di Castri, F. (Eds.), Time Scales of Biological Responses to Water Constraints: The Case of Mediterranean Biota. SPB Academic Publishing, Amsterdam, The Netherlands, 215-237.

35. Spiers, D.E., Spain, J.N., Ellersieck, M.R., Lucy, M.C. (2018): Strategic application of convective cooling to maximize the thermal gradient and reduce heat stress response in dairy cows. Journal of Dairy Science 101, 8269-8283. https://doi.org/10.3168/jds.2017-14283

36. Thompson, J.A., Magee, D.D., Tomaszewski, M.A., Wilks, D.L., Fourdraine, R.H. (1996): Management of summer infertility in Texas Holstein dairy cattle. Theriogenology 46, 547-558. https://doi.org/10.1016/0093-691X(96)00176-8
37. Thornton, P.K., van de Steeg, J., Notenbaert, A., Herrero, M. (2009): The impacts of climate change on livestock and livestock systems in developing countries: A review of what we know and what we need to know. Agricultural Systems 101, 113-127. https://doi.org/10.1016/j.agsy.2009.05.002

38. Titto, C.G., Negrao, J.A., Canaes, T.d.S., Titto, R.M., da Cunha Leme-dos Santos, T.M., Henrique, F.L., Calviello, R.F., Franco Pereira, A.M., Lencioni Titto, E.A. (2017): Heat stress and ACTH administration on cortisol and insulin-like growth factor I (IGF-I) levels in lactating Holstein cows. Journal of Applied Animal Research 45, 1-7. https://doi.org/10.1080/09712119.2015.1091326

39. Verkerk, G. (2009): In summer, shade rules. Australian Agroforestry 63, 2.

40. Wakayo, B.U., Brar, P.S., Prabhakar, S. (2015): Review on mechanisms of dairy summer infertility and implications for hormonal intervention. Open Vet J 5, 6-10.

41. Wilson, S.J., Marion, R.S., Spain, J.N., Spiers, D.E., Keisler, D.H., Lucy, M.C. (1998): Effects of controlled heat stress on ovarian function of dairy cattle. 1. Lactating cows. Journal of Dairy Science 81, 2124-2131. https://doi.org/10.3168/jds.S0022-0302(98)75788-1

42. Wolfenson, D., Thatcher, W.W., Badinga, L., Savio, J.D., Meidan, R., Lew, B.J., Braw-Tal, R., Berman, A. (1995): Effect of heat stress on follicular development during the estrous cycle in lactating dairy cattle. Biology of Reproduction 52, 1106-1113. https://doi.org/10.1095/biolreprod52.5.1106 